\title{
Hermeneutika Insider-Ousider: Studi Atas Pengaruh Heremeneutika Barat Terhadap Heremeneutika Islam
}

\author{
Musnur Hery
}

\section{Pendahuluan}

Salah satu kekayaan khazanah intelektual Islam adalah peninggalan Kitabkitab tafsir klasik yang ditulis oleh sarjanawan dan mufassir muslim ternama. Jumlahnya sangat mengagumkan, mengingat setiap mufassir dalam menafsirkan al-Qur'an melahirkan Kitab yang berjilid-jilid. Namun seiring dengan kemunduran umat Islam, khususnya dalam bidang pengetahuan, kuantitas (bahkan mungkin pula kualitas) volume tafsir tersebut mengalami penurunan tajam. Ditengarai salah satu penyebabnya adalah tertutupnya pintu ijtihad, sehingga masyarakat umum hanya mengikuti eksegesi yang telah dikembangkan dan digariskan oleh ulama'. Dalam tradisi ortodoks otoritas tafsir hanya ada pada sekelompok orang yang dipandang otoritatif, yakni ulama tertentu. ${ }^{1}$

Namun sesungguhnya ada faktor fundamental lain yang bersifat epistemologis yakni langkanya kajian metodologi tafsir dan kurang memadainya kognisi teori tafsir atau teks (hermeneutika). ${ }^{2}$ Dalam tradisi Islam konvensional aspek praksis eksegesi yang lebih dominan. Alfrod T. Welch pernah mengatakan bahwa studi al-Qur'an mencakup tiga bidang:

1. Studi teks al-Qur'an itu sendiri (eksegesi)

2. Sejarah interpretasi al-Qur'an dan perannya dalam kehidupan muslim.

3. Kajian metodologi tafsir. ${ }^{3}$

Ia kemudian menggarisbawahi bahwa mayoritas kaum muslim lebih tertarik pada bidang kajian pertama, sedikit sekali yang menaruh perhatian pada bidang kedua

\footnotetext{
1 Pandangan ini didasarkan kepada tafsir ulama' klasik akan ayat-ayat muhkamat dan mutasyabihat. Ulama' klasik memberikan perbedaan bahwa muhkamat berarti suatu ayat yang mempunyai makna yang tegas dan tertentu (qath'i) sedang mutasyabihat adalah ayat yang pemahamannya melalui makna metaforis. Bagi ayat-ayat atau teks yang seharusnya mempunyai satu makna yang (dipandang) benar maka ini adalah otoritas 'ulama' dalam menafsirkannya yang telah diinstitusionalkan oleh para fuqaha' dalam fiqh, sementara ayat-ayat yang mempunyai makna variatif (metaforis), maka kebenarannya dirujukkan sepenuhnya kepada Allah. Segala masukan, sebagai hasil dari proses pengetahuan, meskipun berasal dari seorang pemeluk Islam yang berbudaya dan terdidik, -- di luar identitas ulama'- maka tidaklah berarti, dalam konteks pemahaman muslim fundamental ini sedikit mempunyai signifikansi. Lihat Jane Dammen McAuliffe, "Qur'anic Hermeneutics: The Views of al-Tabari and Ibn Kathir" dalam Approaches to the History of the Interpretation of the Qur'an, ed. Andrew Rippin (Oxford: Clarendon Press, 1988), hal. 46-62.

2 Lihat Fazlur Rahman "Divine Revelation and The Prophet" dalam Hamdard Islamicus, 3:2 (June: 1964), hal. 170

${ }^{3}$ Lihat Alfrod t. Welch, "Studies in Qur'an and Tafsir" dalam JAAR, vol. 47 (1979), hal. 630.
} 
dan ketiga. Pandangan seperti ini terindikasi dengan terbitnya berjilid-jilid buku tafsir dari berbagai pengarang sarjana muslim, sementara kitab-kitab yang berkenaan dengan bidang kedua dan ketiga tidak sebanding dangan yang pertama.

Kelangkaan metodologi tafsir ternyata juga terjadi pada pembaru atau modernis muslim. Para modernis muslim, yang melihat adanya keterkaitan antara interpretasi al-Qur'an dengan lingkungan orisinil dan kontemporer, semisal Jamaluddin al-Afghani, Muhammad Abduh dan Muhammad Iqbal baru sampai pada taraf menginterpretasikan Islam untuk aplikasi hidup dalam dunia modern ini.. Menurut Tamara Sonn pada pemikiran tokoh-tokoh pos modernis muslimlah seperti Fazlur Rahman, Hasan Hanafi, Mohammed Arkoun, Muhammad al-Jabiri dan Nasr Hamid Abu Zayd, yang di samping menginterpretasikan Islam namun juga mendiskusikan metodologi yang dipakainya. ${ }^{4}$ Meskipun begitu, upaya ke arah formulasi metodologi tafsir dalam dunia Islam sebenarnya sudah dilakukan jauh sebelum modernitas itu sendiri. Hanya saja belum tersistematisasi.

\section{Tradisi Tafsir}

Persoalan pemahaman dan penafsiran tradisi Islam sudah dikenal sejak awal. Pemahaman dan penafsiran ini tidak meluas ke berbagai teks, namun lebih banyak terfokuskan pada al-Quran, karena Kitab inilah yang menjadi pegangan kaum muslimin. Bagi komunitas muslim al-Qur'an merupakan pusat studi utama, karena dipandang sebagai way of life yang mencakup segala aspek kehidupan. ${ }^{5}$ Hanya saja ketika Rasulullah masih hidup, problem pemahaman dan penafsiran tersebut tidaklah berkembang luas di kalangan para sahabat. Ini lebih dikarenakan al-Qur'an turun dalam lingkungan dan berdialog langsung dengan masyarakat. Masalah pemahaman dan penafsiran selanjutnya dikembalikan kepada Rasulullah. Rasulullah lah yang berwenang memberikan tafsir terhadap al-Qur'an, baik ditanyakan langsung oleh para sahabat ataupun tidak. ${ }^{6}$

Pasca Rasulullah, problem pemahaman dan penafsiran memasuki babakan baru dan mulai meluas perkembangannya. Para sahabat tidak lagi menemukan sumber utama tempat mengadukan dan atau memberikan penafsiran. Kondisi seperti inilah yang mengahajatkan Sahabat otoritatif tertentu yang memiliki kewenangan penafsiran al-Qur'an untuk tampil memberikan solusi terhadap penafsiran al-Qur'an. Beberapa sahabat yang memang dikenal kental dengan penulisan dan pemahaman al-Qur'an serta musahabah intens dengan Rasulullah mulai menjadi rujukan bagi penafsiran al-Qur'an semisal Ibn Abbas dan Umar ibn Khattab. ${ }^{7}$

\footnotetext{
${ }^{4}$ Lihat Tamara Sonn, "Fazlur Rahman and Islamic Feminism" dalam Waugh The Shaping of an American Islamic Discourse, Atlanta: Scholar Press, 1998, hal. 125

${ }^{5}$ Lihat Bayard Dodge, Muslim Educationin Medieval Times (Washington: The Midlle Instite, 1962), hal. 31.

${ }^{6}$ Lihat Husein Muhammad al-Zahabi, al-Tafsir wa al-Mufassirun, Juz I, (t.tp: t.p. , 1986), hal. 32 .

${ }^{7}$ Ibid. al-Suyuti menyebutkan sepuluh orang sahabat yang dipandang otoritatif dalam menginterpretasi al-Qur'an; Empat Khalifah (khulafa' al-Rasyidun), Ibn Abbas,. Ibn Mas'ud, Ubay ibn Ka'ab, Zaid ibn Tsabit, Abu Musa al-Asy'ari dan Abdullah Ibn Zubair. Lihat al-Suyuthi, al-Itqan fi Ulum al-Qur'an (Beirut: Dar al-Fikr, t.t.) Vol. I, hal. 187.
} 
Tradisi penafsiran yang dilakukan oleh para sahabat menempuh jalan yang tidak jauh berbeda dengan Rasulullah, artinya penafsiran terhadap al-Qur'an diberikan kepada sahabat lainnya secara langsung melalui lisan atau dialog. Sahabat yang dipandang otoritatif akan memberikan eksplanasi dan intepretasi terhadap persoalan atau pertanyaan yang berkaitan dengan penafsiran al-Qur'an. Dengan demikian tradisi penafsiran yang berkembang adalah tafsir dalam budaya lisan - dari mulut ke mulut. ${ }^{8}$ Sementara itu tafsir dengan pola lisan amat menghajatkan sistem redaksional, suatu mata rantai kondusif bagi berkembangnya pola penafsiran secara riwayat, ${ }^{9}$ dalam artian persyaratan intelektual dan spiritual seseorang menjadi sangat signifikan dalam penyampain riwayat.

Perubahan perkembangan tafsir al-Qur'an mulai nampak pada era tadwin, sebuah periode yang menandai transformasi budaya lisan menuju budaya tulis. Perubahan ini juga berimplikasi pada munculnya tafsir bi al-ra'yi (dirayah) menyusul semakin mapannya tafsir riwayah. Pada era ini, seiring dengan banyaknya kaum muslim mulai menuangkan penafsiran mereka dalam bentuk tulisan, perhatian ke arah metodologi penafsiran pun mulai nampak. Penafsiran tidak semata sebatas apa yang telah ditransmisikan oleh para sahabat, tetapi telah berkoneksi pada aspek bahasa, tradisi etnografis Arab dalam menderivasi makna al-Qur'an serta beberapa pengetahuan alam. Ditambahkan oleh Thameem Ushama, di samping pengetahuan tersebut, pengetahuan akan tata bahasa, retorika, etimologi, prinsip hukum dan prinsip-prinsip asbab al nuzul menjadi bahan pertimbangan utama dalam tafsir bi alra'yi. ${ }^{10}$ Perubahan paradigma tafsir yang sedikit mengarah ke metodologis ini setidaknya dapat terlihat dari beberapa tulisan yang dapat dijadikan indikator: Dalam al-Asyabah wa al-Nazair fi alQur'an al-Karim karangan Maqatil ibn Sulaiman memperlihatkan ketertarikan penulis akan keberagaman makna kata-kata dan ibarat dalam al-Qur'an, tulisan Ma'ani al-Qur'an oleh Abu Zakaria Yahya ibn Zayyad al-Farra' menunjukkan adanya fenomena "pelampauan" dan perluasan makna dalam wacana al-Qur'an. ${ }^{11}$

Upaya yang sangat fundamental dalam merumuskan aturan-aturan dan prinsip-prinsip penafsiran al-Qur'an dilakukan pertama kali oleh Imam Syafi'i dalam kitabnya al-Risalah. Kitab ini memang dapat dikatakan sangat erat dengan Ushul fikih, namun prinsip-prinsip metodologis penafsiran al-Qur'an juga didapati di sini. al-Juwaini menegaskan bahwa belum ada seorang pun yang mendahului Imam Syafi'i dalam merumuskan prinsip-prinsip metodologis

${ }^{8}$ Beberapa orientalis memandang bahwa wacana lisan merupakan tipikal orisinal dari suku Arab. Wacana lisan ini disamping mempunyai kelemahan dalam menenlusuri fakta historis sebagai dokumen bagi pengumpulan data akan suatu bangsa, namun mempunyai kelebihan dalam restorasi dan resistensi akan suatu memori. Lihat misalnya Montgomery Watt, Muslim Christian Enmcounters : Perceptioan and Misperception ( New York: Rouledge and Kegan Paul).

${ }^{9}$ Lazim pula Tafsir seperti ini disebut dengan tafsir bi al-riwayat atau al-ma'thur, lihat misalnya Thameem Ushama, Methodologies of Qur'anic Exegesies (Kuala Lumpur: A.S. Nordeen, 1995), hal. 7.

${ }^{10}$ Thamem Ushama, Methodologies of Qur'anic Exegesies., hal. 18-19.

${ }^{11}$ M. Nur Ikhwan, Hermeneutika Al-Qur'an: Analisis Peta Perkembangan Metodologi Tafsir Al-Qur'an Kontemporer (Yogyakarta, t.p., 1995), hal. 39. 
keilmuan Islam. ${ }^{12}$ Upaya mengkaitkan antara metodologi penafsiran al-Qur'an dan Ushul fikih yang dilakukan Imam Syafi'i ini sangat berarti, bahkan dalam beberapa hal masih mempengaruhi pemikiran hermenutis yang dikembangkan pada era kontemporer. ${ }^{13}$

Secara garis besar upaya yang dilakukan Imam Syafi'i menekankan pada pemahaman teks, bagaimana dapat memahmai apa yang dimaksud "pembicara" dalam teks (al-Qur'an atau sunnah). ${ }^{14}$ Pemahaman teks seolah menjadi tertutup karena hanya tertuju pada salah satu unsur -yang dipandang pokok- yakni maksud pembicara. Sebaliknya, upaya metodologi interpretasi yang dilakukan alJahiz pada masa berikutnya menekankan pada upaya yang belum dilakukan oleh al-Syafi'i yakni aspek audiens atau world of reader dengan jalan membuat wacana tersebut dapat dipahami oleh audiens. Disini interpretasi metodis yang dikembangkan lebih bersifat ekstrovet.

Kedua upaya yang terkesan bersebrangan dari kedua sarjana muslim di atas dijembatani oleh Muhammad ibn Abdul Wahhab dengan menggabungkan kedua metodologi di atas yaitu dengan menggabungkan pembahasannya pada masalah lafadz dan makna dengan mengkaitkannya pada pembahasan ahli ushul tentang khabar, qiyas, syarat-syarat validitas dan tingkatan kebenaran. ${ }^{15}$

\section{Ke Arah Hermeneutika al-Qur'an}

Upaya-upaya yang telah disebutkan disini tadi masih bersifat hermeneutika al-Qur'an secara tradisional. Meskipun kemunculannya sudah mulai dekade 1960 an, namun hermenutika mendapatkan sambutan hangat pada akhir dekade 1970, tepatnya setelah Fazlur Rahman merumuskan sistematika hermeneutika-nya. Beberapa tahun sebelumnya Arkoun pernah menawarkan "cara baca“" semiotik dalam penafsiran al-Qur'an, namun tidak mendapatkan sambutan hangat di dunia Islam. Tidak diketahui secara pasti penyebab hal demikian. Hanya saja pasca Fazlur Rahman memperkenalkan hermeneutika di dunia Islam, pemikiran Arkoun tentang "cara baca" tersebut mulai ramai didiskusikan kembali, tidak terkecuali di Indonesia. Atas asumsi ini, tidaklah berlebihan bila Fazlur Rahman dianggap sebagai tokoh yang berjasa besar dalam menumbuhkembangkan kesadaran baru di kalangan kaum muslimin tentang bagaimnana seharusnya merekonstruksi penafsiran al-Qur'an.

Hal yang perlu digarisbawahi, meskipun hermeneutika yang dikembangkan dalam Islam adalah hermeneutika al-Qur'an, namun sesungguhnya tidak bisa dilepaskan sama sekali dari pengaruh hermeneutika di Barat (sebagai tempat asalnya), sebagaimana akan terlihat awalnya pada pemikiran Fazlur Rahman. Juga dapat ditambahkan pula, meskipun istilah hermeneutika baru dikenal dekade 1960, tidaklah dapat dikatakan bahwa hermeneutika adalah barang baru dalam pemikiran Islam. Ini, sebagaimana ditandaskan sebelumnya, karena

12 Lihat khalid Abdurrahman al-“Ak, Ushul al-Tafsir wa Qawa'iduhu (Beirut: Dar alNafais, 1986), hal. 35 .

${ }^{13}$ Contoh yang amat mudah adalah apa yang dilakaukan oleh Fazlurrahman Hanafi.

14 'Abid al-Jabiri, Binyah al-'Aql al-'Arabi, (Beirut: Markaz Dirasat Wahdah al'Arabiyah, 1989), hal. 32.

${ }^{15}$ Nur Ikhwan, Hermeneutika Al-Qur'an, hal. 42. 
berkaitan dengan masalah metodologi dan teori interpretasi. Artinya hermeneutika al-Qur'an dapat diterapkan dalam metodologi dan teori penafsiran al-Qur'an yang dirumuskan oleh para pakar tafsir klasik.

Sebenarnya pemikiran hermeneutis dalam tradisi Islam kontemporer tidaklah semata pemberian dari peneliti luar, namun juga telah dipergunakan oleh kalangan Islam sendiri untuk memperlihatkan pemikiran metodologi tafsir mereka. Pemikir-pemikir muslim kontemporer telah memperlihatkan beberapa pemikiran mereka tentang metodologi tafsir yang mendapatkan banyak sambutan di kalangan akademisi. Pada perkembangan awal hermeneutika ini pijakan kontekstual-historis masih sangat kental. Beberapa tokoh yang akan diperlihatkan di bawah ini memperlihatkan kecenderungan metodologi tafsir ini..

\section{Maulana Farid Essack}

Pemikiran metodologi penafsiran juga mendapatkan perhatian yang besar dari Maulana Farid Essack, seorang tokoh pembaru muslim dari belahan wilayah minoritas muslim Afrika Selatan. Latar belakang munculnya pemikiran metodologis al-Qur'an dari Farid Essack adalah situasi politik ekonomi kaum muslim yang tertindas oleh sistem Apartheid di Afrika Selatan.

Sebagai kaum minoritas, kaum muslimin, seperti halnya kaum kulit hitam pada umumnya, mencari solusi untuk terlepas dari belenggu penindasan yang mereka alami. Untuk itulah mereka mencari solusi tersebut dari kitab Suci mereka - dalam hal ini adalah al-Qur'an. Al-Qur'an dipahami secara tipikal; sebagai sumber inspirasi pembebasan dari penindasan dan ketidak-adilan. Farid Essack melihat persoalan mendasar bahwa pencarian makna dan menginterpretasi al-Qur'an yang dilakukan kalangan organisasi kepemudaan Islam -bukan ulama' tradisional- dalam memberikan solusi atas problematika di atas tidak memiliki landasan metodologis yang sistematik.

Pemikiran hermeneutika Farid Essack banyak tersebar di berbagai karangan ilmiahnya. Bagi Farid Essack hermeneutika mengasumsikan bahwa setiap orang yang berhadapan dengan teks membawa pertanyaan dan harapannya sendiri dan adalah sangat absurd untuk menuntut dari seseorang penafsir tersebut untuk memformat sesuatu di luar subjektivitasnya sendiri, yang itu berarti teks tersebut menjadi mati di hadapan seorang penafsir. Untuk itu seseorang ketika berhadapan dengan teks al-Qur'an, pertanyaan yang muncul tentang makna dan otoritas suatu teks (al-Qur'an) sangat berkaitan dengan pertanyaan yang berkenaan dengan hakikat teks itu sendiri (alQur'an). ${ }^{16}$ Bagi masyarakat muslim Afrika Selatan hakikat teks atau al-Qur'an adalah penggunaan dan tanggapan yang dapat berbeda-beda dalam situasi sosio politik tertentu; hakikat al-Qur'an sesuai dengan perbedaan dan jalan pemahaman masyarakat.

Dari sinilah kemudian ia menggariskan "hermeneutika reseptifnya". Farid Essack mendasarkan pemikiran "hermeneutika tanggapannya" pada teori Buckley bahwasannya hermeneutika tanggapan senantiasa mempunyai

16 Farid Essack, Qur'an, Liberation and Pluralisme: An Islamic Perspective of Interreligious Solidarity against Oppression (Oxford: Oneworld, 1997), hal. 51. 
kategori fungsionalisme dalam studi teks. Fungsionalisme sangat berlawanan dengan reveliasionisme, dimana fungsionalisme memfokuskan pada penggunaan teks dan mengklaim bahwa teks-teks tertentu dapat disebut sebagai Kitab suci bila telah melampaui even pragmatis dan fungsional bagi manusia. ${ }^{17}$ Hermeneutika tanggapan memiliki fokus kajian pada proses penafsiran dan kelayakan penafsiran ketimbang pada teks literal yang mati. Menurut Fiorenza, tokoh yang banyak pula mempengaruhi Essack, penafsiran semacam ini tidak hanya perlu mempertimbangkan teks dan audiens orisinalnya, tetapi juga tranformasi antara horizon masa lalu dan masa kini. ${ }^{18}$

Dalam metode dan pendekatan yang diambil, Farid Essack banyak mengkontribusi pemikiran Arkoun. Ia menerapkan metode yang dimaksudkan Arkoun untuk menguak lapisan-lapisan nalar di balik teks-teks keagamaan klasik $^{19}$ Farid Essack menawarkan metode hermeneutikanya dengan sebutan regresif-progresif.

Sebelum menawarkan metode interpretasinya, Farid mensyaratkan akan adanya keys of understanding agar hermenutika pembebasan al-Qur'an dapat menselaraskan antara teks dan konteks beserta implikasinya satu sama lain. ${ }^{20}$ Ada beberapa kunci pemahaman yang ditawarkan: Pertama takwa, kedua tauhid, ketiga, masyarakat atau manusia, keempat mustadh 'afin atau golongan marginal, kelima keadilan dan keseimbangan dan terakhir jihad. Yang pertama dan kedua dimaksudkan untuk mengembangkan kriteria moral dan doktrinal untuk menguji aktualitas kunci-lainnya dalam pemahaman dan mengembangkan wacana teologis dalam mengkaji al-Qur'an secara holistik dan secara spesial teks yang menyangkut keberagamaan lainnya. Yang ketiga dan keempat mendefinisikan lokasi aktifitas interpretasi. Sementara dua yang terakhir merefleksikan metode dan etos yang memproduksi dan membentuk sebuah pemahaman kontekstual al-Qur'an dalam sebuah masyarakat yang tidak adil. $^{21}$

Metode interpretasi yang digagas Farid Essack terdiri dari dua prosedur yakni prosedur regresif dan prosedur progresif.

a. Prosedur regresif adalah kembali ke masa lalu secara kontinyu bukan untuk sekedar memperhitungkan kebutuhan-kebutuhan dan keinginankeinginan masa kini atas teks-teks fundamental, tetapi juga untuk mengungkap mekanisme historis dan faktor-faktor yang memproduksi teks-teks ini dan memberikan fungsi-fungsi tertentu terhadapnya. Pemaknaan proses pewahyuan al-Qur'an haruslah dipahami dalam konteks tertentu. Proses pemahaman ini haruslah bekerja dalam konteks personal sosial masa kini yang berada dalam situasi penindasan dan perjuangan untuk membebaskan diri.

${ }^{17}$ Ibid.

18 Fiorenza, "The Crisis of Scriptual Authority: Interpretation and Reception", dalam Interpretation, vol. 44 No. 4 (Oktober, 1990).

${ }^{19}$ Sebagaimana dikutip Nur Ikhwan, Hermeneutika Al-Qur'an, hal. 92.

${ }^{20}$ Farid Essack, Qur'an, Liberation and Pluralisme, hal. 86.

${ }^{21}$ Ibid. 
b. Prosedur yang kedua berkaitan teks-teks yang merupakan bagian yang tak terpisahkan dari identitas kaum muslimin di Afrika Selatan, dan aktif dalam sistem ideologi mereka, teks-teks ini harus diperhitungkan kembali agar dapat memperoleh suatu makna kontemporer dan kontekstual. Untuk itulah diperlukan prosedur kedua, prosedur progresif; memeriksa proses transformasi muatan-muatan dan fungsi-fungsi awal ke dalam muatan dan fungsi baru.

Dalam menggariskan kedua metode interpretasi di atas, Farid Essack memanfaatkan ushul tafsir dan ushul fikih. Pada prosedur pertama, Farid Essack memandang perlunya mempertimbangkan naskh, asbab al-nuzul, dan ilm al-makki dan al-madani. Dalam prosedur kedua, dimanfaatkan metodemetode ushul fikih sepert istihsan, 'urf dan al-mashlahah al- 'ammah. ${ }^{22}$

Meskipun Essack tidak secara eksplisit menyatakan kontribusi pemikiran Rahman dalam hermeneutikanya, namun secara faktual gagasan-gagasannya juga diilhami oleh tokoh satu ini - disamping tokoh-tokoh yang lain tentunya. Pandangan Rahman bahwa al-Qur'an merupakan respon terhadap situasi moral yang dihadapi kaum muslim selaras dengan pandangan ontologis dan aksiologis hermeneutika Farid Essack. ${ }^{23}$ Prosedur regresif dan progressif dalam aktivitas interpretasinya sangat mirip sekali dengan double movement Rahman, termasuk seperangkat ilmu yang dibutuhkan ke dalam dua prosedur tersebut. Paling tidak ini memperlihatkan bahwa hermeneutika Fazlur Rahman, sebagai pembaru muslim yang dipandangnya membangkitkan minatnya dalam peletakan metodologi interpretasi (hermeneutika al-Qur'an), ${ }^{24}$ memberikan inspirasi bagi metodologi interpretasi Farid Essack, sehingga ia merasa perlu untuk mengelaborasi pemekiran hermeneutis Rahman dalam sub bab karyanya. ${ }^{25}$

2. Aminah Wadud Muhsin

Aminah Wadud Muhsin adalah seorang sarjana Malaysia yang banyak menaruh perhatian tentang masalah perempuan dalam al-Qur'an. Memang dalam kajian feminisme, di kalangan muslim sudah banyak tokoh yang muncul, namun Aminah Wadud memiliki keunggulan metodologis dalam memahami al-Qur'an dibandingkan lainnya.

Dalam menafsirkan al-Qur'an, Aminah menawarkan suatu metode tafsir yang dipandangnya terbaik dan relaitf baru serta tidak ada pertimbangan substansial mengenai isu-isu tertentu tentang perempuan dalam kaintannya dengan keseluruhan al-Qur'an dan prinsip-prinsip pokoknya. Tafsir yang menggunakan metode ini dinamakannya dengan tafsir holistik, yakni penafsiran yang mempertimbangkan kembali seluruh metode penafsiran al-

\footnotetext{
${ }^{22}$ Nur Ikhwan, Hermeneutika Al-Qur'an, hal. 94.

${ }^{23}$ Lihat misalnya Farid Essack, "Contemporary Religious Thought in South Africa and the Emergence of Qur'anic Hermeneutical Notions" dalam ICMR, 002: 002 1991, hal. 206-226.

${ }^{24}$ Farid Essack, Qur'an ..., hal. 11, 64.

${ }^{25}$ Ibid., hal. 63-68.
} 
Qur'an yang dikaitkan dengan berbagai persoalan sosial, moral, ekonomi, dan praktek modern. $^{26}$

Dalam pandangannya terhadap al-Qur'an Aminah Wadud menegaskan bahwa agar dapat terpelihara relevansi al-Qur'an dengan kehidupan manusia, al-Qur'an mau tidak mau harus terus menerus ditafsirkan ulang. ${ }^{27}$ Aminah Wadud membagi penafsiran menjadi dua peringkat: membaca dan menafsirkan. Pada tingkat membaca, pembaca bisa menafsirkan al-Qur'an seraya membacanya. Pada tingkat penafsiran upaya dibuat untuk tercapainya perspektif individual yang lebih baik sehingga mampu mendekati al-Qur'an secara objektif. Disinilah signifikansi hermeneutika. Hanya saja, lanjut Aminah, tidak ada satu penafsiran yang dapat dipisahkan dari pengaruh pribadi pembaca atau penafsir dan menghilangkan pengaruh prior text dari interpretasinya $^{28}$ Untuk itu tidak ada metode penafsiran al-Qur'an yang sepenuhnya objektif, karena setiap penafsiran membuat sejumlah pilihan yang bersifat subjektif. Demikian pula tidak ada penafsiran yang bersifat defenitif, pasti dan desitif. ${ }^{29}$ Meskipun demikian, dalam al-Qur'an, untuk menghindari relativisme, terdapat kesinambungan dan ketetapan dalam teksnya yang dapat digunakan sebagai contoh teladan, di samping setiap konteks sosial harus memahami prinsip mendasar ayat dan prinsip tidak dapat dirubahnya ayat alQur'an. ${ }^{30}$

Aminah menggagas landasan yang harus menjadi pijakan dalam hermeneutika feminismenya sebagai berikut:

a. Al-Qur'an adalah petunjuk universal yang tidak terikat ruang dan waktu yang dengan begitu pernyataannya bersifat abadi, tidak membedakan jenis kelamin.

b. Dikarenakan al-Qur'an dengan mulus dapat diadaptasi dalam konteks perempuan dan masyarakat Rasulullah abad ke $7 \mathrm{M}$, maka al-Qur'an harus pula dapat diadaptasi dalam konteks perempuan modern.

c. Pandangan baru mengenai peran perempuan haruslah dilakukan melalui kaji ulang al-Qur'an berikut prinsip-prinsip keadilan sosial, persamaan manusia serta tujuannya sebagai pedoman universal manusia.

d. Selama ini penafsiran tentang perempuan dalam al-Qur'an ditafsirkan hanya oleh kaum pria dengan pengalaman prianya. Untuk itu sekarang haruslah ayat-ayat al-Qur'an tentang perempuan ditafsirkan oleh perempuan sendiri dengan pengalaman perempuan dengan tanpa stereotif terhadap penafsiran yang dilakukan kaum pria. ${ }^{31}$

Adapun metode dan pendekatan yang dikembangkannya selalu berhubungan dengan tiga aspek teks :

a. Dalam konteks apa ayat itu diturunkan.

${ }^{26}$ Aminah Wadud Muhsin, Wanita dalam al-Qur'an, terj. (Bandung: Pustaka, 1994), hal.

xxi.

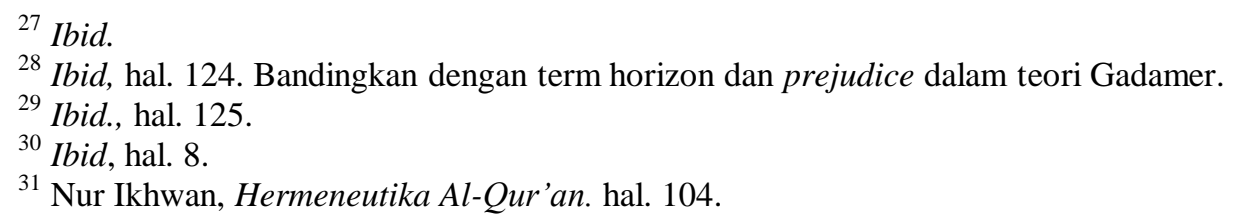


b. Bagaimana komposisi tata bahasa teks itu.

c. Bagaimana keseluruhan teks, atau pandangan hidupnya. ${ }^{32}$

Ayat-ayat yang terkait dengan perempuan dianalisis dengan menggunakan tafsir al-Quran bi al-Qur'an, dengan prosedur analisis :

a. Dalam konteksnya.

b. Dalam konteks pembahasan topik serupa dalam al-Qur'an.

c. Menyangkut soal bahasa yang sama dan struktur sintaksis yang digunakan di seluruh bagian al-Qur'an.

d. Menyangkut sikap benar-benar berpegang teguh pada prinsip alQur'an.

e. Dalam konteks al-Qur'an sebagai pandangan hidup manusia. ${ }^{33}$

Adapun bagian penting dari analisis Amina Wadud adalah :

a. Bentuk feminin dan maskulin yang digunakan dalam al-Qur'an.

b. Sejumlah kata kunci tertentu dan dikaitkan dengan manusia secara umum dan perempuan secara khusus, agar mengungkapkan pemahaman kontekstualnya. ${ }^{34}$

Agar dapat memuluskan penafsiran feminismenya, Aminah mendekati ayat-ayat al-Qur'an "dari sisi luar", berusaha agar tidak terjebak dalam konteks bahasa yang membedakan jenis kelamin, karena tipologi bahasa dalam al-Qur'an menggunakan pembedaan gender. ${ }^{35}$

Secara umum metode yang digunakan Aminah sejalur dengan apa yang digunakan oleh Fazlur Rahman: Dari masa kini, ke masa al-Qur'an diturunkan dan kembali lagi masa kini. Gerak pertama berkaitan dengan metode yang baru dijelaskan di atas, sementara gerak kedua ada dalam kriteria penafsiran terhadap al-Qur'an yang telah diuraikan sebelumnya.

3.Fazlur Rahman

Boleh dikatakan Fazlur Rahman adalah pemikir muslim yang dipandang sebagai pionir bagi hermeneutika al-Qur'an. Nahkan bagi ke daua pemikir yang disebutkan sebelumnya metodologi tafsir Rahman sangat menmpengauhi mereka. Fazlur Rahman yang sedang intens-intensnya menggeluti wacana hermeneutika untuk proyek hermeneutika al-Qur'annya sangat dipengaruhi oleh perdebatan dua hermeneut ini. Untuk itu sedikit ulasan seputar perdebatan antara keduanya akan memperlihatkan benang merah kontribusi mereka dalam hermeneutika Fazlur Rahman.

Kedua hermeneut ini sebenarnya mewakili dua kutub tradisi hermeneutika yang berbeda dalam memandang hermeneutika. Emilio Betti sebagai pengikut Schleiermacher dan Dilthey mneneruskan tradisi yang melihat hermeneutika sebagai prinsip-prinsip umum yang mendasari interpretasi. Sementara Gadamer penerus Hedegger lebih melihat hermeneutika sebagai eksplorasi filosofis dari karakter dan kondisi yang dibutuhkan bagi semua

\footnotetext{
${ }^{32}$ Amina Wadud, Wanita dalam al-Qur'an, hal. 2, 4 dan 126.

${ }^{33}$ Ibid., hal. 7.

${ }^{34}$ Ibid., hal. 8,9 .

${ }^{35}$ Ibid.
} 
pemahaman. ${ }^{36}$ Dari sini jelas bahwa Betti dan mazhabnya melihat hermeneutika sebagai fondasi metodologis, sementara Gadamer dan kelompoknya lebih ke arah ontologis. Dan hasilnya, yang pertama menganut interpretasi objektif sedangkan kedua menganut interpretasi relatif.

Kritik Betti kepada Gadamer sebenarnya merupakan "the battlle" jilid dua, setelah sebelumnya Gadamer melakukan kritik terhadap mazhab Dilthey. Kecenderungan metodik aliran Hermeneutical Theory diserang habis oleh Gadamer dalam magnum Opusnya Truth and Method. Gadamer menyatakan : I did not intend to produce a manual for guiding understanding in the manner of earlier hermeneutics. I did not wish to elaborate a system of rulers to describe, the methodical procedure of the human sciences ... My real consern was and is philosophic, not what we do or what we ought to do, but what happens to us over and above our wanting. ${ }^{37}$

Sindiran Gadamer ini ditujukan kepada pendahulunya Schleiermarcher dan Dilthey yang membasiskan aturan metodisnya pada kecenderungan "general

${ }^{36}$ Richard E. Palmer, Hermeneutics, hal. 52.

${ }^{37}$ Hans Gadamer, Truth and Method, hal. xvi.

Statemen diatas adalah salah satu contoh dari banyak kritik pedas Gadamer terhadap hermeneutical theory khususnya, dan prosedur metodis dari ilmu-ilmu kemanusiaan (human sciences, geiteswissenschaften) pada umumnya. Secara umum kritik Gadamer ditujukan pada dominasi empirisme-positivisme (formal logis) yang terutama secara gencar diaplikasikan oleh para Kantian. Dalam magnum Opus tersebut secara panjang lebar Gadamer menguraikan bagaimana human sciences pada abad 19 secara penuh didominasi model natural sciense. Human sciences memahami dirinya dengan analogi terhadap natural sciences. Dalam hal ini inductive logic John Stuart Mill, yang merupakan basis 'experimental sciences' seolah-olah menjadi takaran. Human sciences diamti melalui penetapan-penetapan similaritas, regularitas dan konformitas terhadap suatu hukum (aturan) yang dimungkinkan dapat memprediksi fenomena dan proses individual.

Gadamer selanjutnya menguraikan keterbatasan dan kelemahan pendekatan metodis. Dalam lapangan fenomena tujuan prediksi ini tidak selamanya dapat dicapai, apalagi dalam aspek moral dan fenomena sosial. Penerapan dalam hal fisik data kuantitatif acap kali tidak sempurna dan untuk itu prediksinya tidak menentu, maka kebenaran yang sama dan bahkan lebih ironis akan terjadi pada fenomena sosial. Penggunaan metode induktif biasanya lepas dari asumsi metafisis dan tetap bebas dari pemikiran seseorang tentang realisasi fenomena sosial yang sedang diamati. Seseorang akhirnya tidak dapat menemukan penyebab dari efek-efek partikular, tetapi hanya secara sederhana menetapkan regularitas. Karena sains adalah suati mode pengalaman hermeneutik universal dari pemahaman manusia, perolehan kebenaran oleh sains pada hakikatnya secara toptalitas tidak dapat tereduksi oleh garansi yang diketengahkan oleh metodological activity. Lihat Francis J. Ambrosio "Gadamer, Plato and the Discipline of Dialogue" dalama International Philosophy Quaterly, vol. 27, 1987, hal. 17.

Sains adalah pemahaman reflektif, ia mengklaim tidak semata untuk memperoleh 'true knowledge', tapi lebih untuk menguji secara reflektif kondisi-kondisi fondasional dari klaim yang ia buat. Refleksi sains hanya satu form pemahaman manusia, dan bahwasannya objektifitas metodologis adalah kriteria kebenaran yang tepat bagi satu jalur pemahaman partikular sains. Dengan demikian, lanjut Gadamer, reflective sciences, karena ia satu mode pemahaman di antara lainnya semisal sejarah, moral, agama dan filsafat, tidak dapat divonis sebagai paradigma spesifik bagi hakikat pemahaman secara umum. Ibid, hal. 18-19. Lihat juga James B. Reichman "Language and the Interpretation of Being in Gadamer and Aquinas" dalam The American Catholic Philosophical Association, Vol. 62, 1988, hal. 225. 
subjectivizing of thouht" Kant. ${ }^{38}$ Kedua hermeneut ini, melalui "subjective selfcertainty" melihat bahwa pemahaman, apapun objeknya, memunculkan daya kreatif dan imajinatif dari subjek yang bekerja dalam akal dengan mengikuti kaidah tahapan penalaran yang runtut dan benar. Objek berupa text, bagi Schleier marcher, kebermaknaannya harsu disingkap melalui suatu rekonstruksi disiplin. Dengan begitu, suatu proses yang secara metodologis dapat mengontrol interpretasi dapat mengadopsi makna dari pengarang. ${ }^{39}$ Sebagaimana pendahulunya Dilthey mengidentifikasi makna teks melalui maksud subjektif pengarangnya. Ia menegaskan: understanding is essentially a self transposition or imaginative projection whereby the knower negates the temporal distances that separates him from his object and becomes contemporaneous with it. ${ }^{40}$ Untuk sampai pada makna objektif yang diingini pengarangnya maka menurut Dilthey objektivitas pengetahuan harus dipenuhi melalui pembebasan ide-ide dan nilainilai personal terhadap suatu subjek dan open mind (geist) terhadap dunia ide-ide dan nilai-nilai masa lalu. ${ }^{41}$

Gadamer mengkritik tajam bangunan hermeneutik kedua filosuf di atas dengan analisa bahwa bagi kedua hermeneut tersebut situasi kekinian reader hanya memiliki nilai negatif, yang dengan begitu pemahaman historikal menurut konsepsi mereka merupakan aksi subjektifitas menghalau segala bentuk prasangka (prejudice) dan dapat dicapai dalam proporsi langsung, mengenyampingkan horizon reader sendiri dalam kerangka metodologis. ${ }^{42}$ Upaya metodologis, lanjut Gadamer, dengan alienasi historisitas pembaca dan menitik beratkan hanya pada kondisi subjektif sesungguhnya bersifat ahistoris, distortif, reproduktif dan tidak dapat menghadirkan format interpretasi yang utuh dan filosofik. ${ }^{43}$

Betti menjawab kritik Gadamer terhadap "guru" nya bahwa sebenarnya proyek interpretasi hermeneutical theory tidak bermaksud

${ }^{38}$ Gadamer Truth..., hal. 10-73. Lihat juga Palmer, hal. 167.

${ }^{39}$ Josep Bleicher, Contemporary... hal. 111. Lihat pula Gadamer, Philosophical... hal. xiii. Juga lihat Joel C. Weisheimer, Gadamer's, Hermeneutics: A Reading of Truth and Method, (New York: Yale Univ. Press, 1985), hal. 131.

${ }^{40}$ Gadamer, Philosphical... hal. xiv.

${ }^{41}$ Palmer, Hermeneutics, hal. 181.

${ }^{42}$ Gadamer, Truth ..., hal. 238.

${ }^{43}$ Hal lain yang dilihat Gadamer kurang bermakna dalam hermeneutical theory adalah mekanisme nihil prasangka (prejudice/prejudgement). Aliran objektivisme menekankan bahwa objektivitas pengetahuan hanya dapat dipenuhi melalui pembebasan dari ide-ide dan nilai-nilai personal terhadap suatu objek dan open mind (geist) terhadap dunia ide dan nilai-nilai masa lalu. Eksplorasi ini bagi Gadamer sebenarnya menegasikan predikat relativisme sesuatu (seseorang) yang semestinya tidak dapat dihakimi dalam tema orang lain. Gadamer memandang "prasangka" ini sebagai suatu keniscayaan. Sebenarnya, ujar Gadamer, suasana kekinian tidak dapat ditinggalkan untuk menuju ke masa lampau; kebermaknaan karya-karya masa lalu tidak dapat dipandang sebagai sesuatu yang berdiri sendiri dalam temanya sendiri. Bahkan sebaliknya, kebermaknaan karya masa lampau harus didefenisikan dalam team-tema berupa pertanyaan yang ditujukan kepadanya dari suasana kekinian. Lihat Palmer, Hermeneutics, hal. 181. Pertanyaanpertanyaan itulah yang disebut dengan prejudice, dan prejudice ini bagi Gadamer adalah bias keterbukaan, lihat Gadamer, Phiklosophical... hal. xv. Gadamer menyakatan: untuk menjadi historikal, sesuatu tidak boleh larut dalam pengetahuaan seseorang. 
menghilangkan momen subjektif dari interpretasi, atau bahkan menolak bahwa hal itu dibutuhkan dalam peristiwa interpretasi manusia. Betti bermaksud mengafirmasi, apapun kemungkinan peran subjektif dalam interpretasi bahwa objek tetap menjadi objek dan sebuah interpretasi yang valid dan objektif dapat layak diusahakan dan diselesaikan. ${ }^{44}$

Terlihat jelas di sini bahwa Betti ingin menunjukkan ketetapan hatinya akan objektivitas interpretasi. Bagi Betti objek interpretasi merupakan objek spirit manusia (geist) yang diungkapkan dalam bentuk perasaan. Dengan begitu interpretasi adalah pengakuan dan rekonstruksi makna yang, dengan menggunakan macam-macam kesatuan khusus dari materi-materi, dapat dibentuk oleh pengarangnya. Artinya seorang peneliti harus menerjemahkan dirinya dalam subjektifitas asing dan, melalui inversi proses kreatif, ia kembali lagi kepada ide atau "interpretasi" yang dibutuhkan ke dalam objek tersebut. Betti jelas terkesan mengarahkan interpretasi kepada Auslegung (interpretasi objektif) lebih dari sekadar singebung (interpretasi iru sendiri/penafsir memberi makna pada objek) sebagaimana yang dianut Gadamer yang dibahasakan oleh Thiselton sebagai pertama teks mentransformasi pembaca dan kedua pembaca mentransformasi teks. $^{45}$

Prinsip otonomi objek hermeneutika Betti di atas merupakan norma dasar (pertama) dari empat norma interpretasi objektif Betti. Norma kedua adalah konteks makna, atau totalitas di mana bagian-bagian individu ditafsirkan. Terdapat relasi dalam (inner relation-ship) dari koherensi antara bagian-bagian pembicaraan individu disebabkan oleh keterlingkupan totalitas makna yang dibangun dari bagian-bagian individu. ${ }^{46}$ Norma yang ketiga adalah Topikalitas (aktualitas) makna, yaitu keterkaitan dengan pendirian dan kepentingan penafsir dalam situasi sekarang, yang dilibatkan dalam setiap pemahaman. Di sinilah penafsir melacak kembali proses kreatif dan membangun kembali dalam dirinya bagian masa lalu sebagai "peristiwa" ke dalam aktualitas kehidupannya sendiri. Hal ini menurut Betti tidak dapat dipahami bahwa pemahaman merupakan persoalan penerimaan pasif; malahan pemahaman selalu merupakan proses rekonstruktif yang melibatkan pengalaman penafsir tentang dunia. ${ }^{47}$ Norma yang terakhir adalah hubungan makna hermenutika atau harmonisasi di mana penafsir mengatasai subjektifitasnya. Dalam kaitannya dengan ini, penafsir membawa "aktualitasnya sendiri ke dalam keselarasan terdekat dengan stimulasi yang ia terima dari objek sedemikian rupa sehingga satu suara dan lainnya berada di jalan yang selaras (resonansi). ${ }^{48}$

Dengan menggaris bawahi bahwa tugas interpretasi adalah memahami prinsip-prinsip dari al-Qur'an (Allah) dan situasi objektif adalah suatu sine qua non bagi pemahaman, khususnya karena memandang normativitasnya bagi kaum

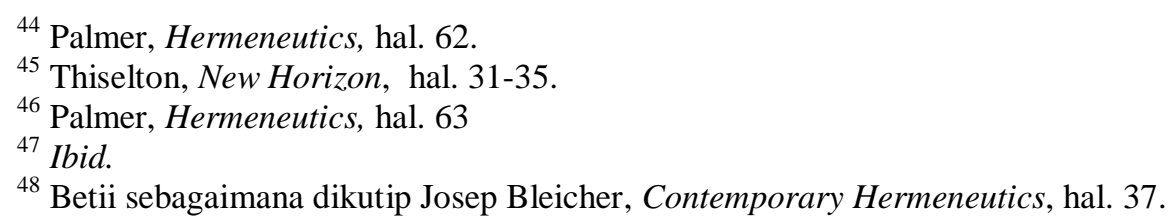


muslim, al-Quran secara harfiah adalah respon Tuhan melalui pikiran Muhammad (faktor yang terakhir ini secara radikal telah diremehkan oleh ortodoksi Islam) terhadap suatu situasi hirtoris, ${ }^{49}$ maka, melalui perdebatan panjang antara Gadamer dan Betti, posisi Fazlur Rahman terlihat cenderung kepada aliran objektifitas dalam mengedepankan interpretasi objektif. Secara khusus tugas interpretasi yang dikedepankan Rahman selaras dengan tugas interpretasi Betti: ".... untuk memahami makna bentuk-bentuk ini, untuk mengungkapkan pesan yang ingin mereka sampaikan kepada kita". Interpretasi merupakan sebuah aktifitas bertujuan yang bertugas membawa kepada sebuah pemahaman. ${ }^{50}$ Secara jujur Rahman mengakui bahwa pandangannya kembali kepada ajaran atau pikiran "pengarang" al-Qur'an dipengaruhi oleh pemahaman sebagai rekonstruksi maksud pengarang ${ }^{51}$ Betti. Meskipun demikian, Rahman juga melampaui Betti di mana ia menambahkan bahwa penisbatan tersebut tidak hanya kepada pikiran pengarangnya, namun juga kepada situasi terhadap mana ia menjadi respon. ${ }^{52}$

Interpretasi historis Rahman yang dijabarkannya melalui double movement bila diamati secara seksama selaras dengan empat norma yang ditawarkan Betti. Ibrahim Mousa melihat gerak ganda hermeneutika Rahman merupakan kependekan dari empat norma tersebut, ${ }^{53}$ sebagaimana Josep Bleicher menyederhanakan empat norma interpretasi Betti menjadi dua klasifikasi besar;

1. Norma terhadap objek, terdiri dari :

a. Norma otonomi hermeneutis.

b. Norma totalitas dan koherensi evaluasi hermeneutis.

2. Norma terhadap subjek interpretasi, yang meliputi :

a. Norma aktualitas pemahaman.

b. Norma harmonisasi pemahaman korespondensi hermeneutis. ${ }^{54}$

Dalam rangka memahami prisnisp-prinsip al-Qur'an dan kemudian mengaplikasikannya ke dalam kehidupan modern, Rahman mengajukan proses interpretasi yang ia sebut dengan double movement. ${ }^{55}$ Secara singkat gerakan ini dimulai dari situasi kekinian sang pembaca menuju kepada saat-saat al-Qur'an diturunkan dan kemudian kembali menuju situasi kekinian. Dalam buku Islam and Modernity Rahman menjelaskan secara rinci teknik ini. ${ }^{56}$ Gerakan pertama mencakup dua langkah :

a. Memahami arti atau makna dari pernyataan tertentu melalui studi situasi historis atau problem di mana pernyataan tersebut merupakan jawabannya.

\footnotetext{
${ }^{49}$ Rahman, Islam and Modernity, hal. 8.

${ }^{50}$ Josep Bleicher, Contemporary Hermeneutics, hal. 29.

${ }^{51}$ Islam, hal. 8 dan juga lihat Josep Bleicher, Contemporary Hermeneutics, hal. 33.

${ }^{52}$ Islam \& Modernity, hal. 8.

${ }^{53}$ Rahman, Revital and Reform, hal. 21.

${ }^{54}$ J. Bleicher, Contemporary Hermeneutics, hal. 37.

${ }^{55}$ Bandingkan dengan "'the fusion of horizon" dari Gadamer Truth and Method, hal. 352.

${ }^{56}$ Rahman, Islam \& Modernity., hal. 6.
} 
b. Mengeneralisir jawaban-jawaban khusus tersebut dan kemudian mempernyatakannya sebagai pernyataan sosial-moral objektif yang dapat disaring dari teks-teks khusus dalam sinaran latar belakang sosio-historis.

Tugas pemahaman dalam langkah pertama adalah pemahaman akan makna al-Qur'an sebagai suatu keutuhan sebaik pemahaman dalam tema prinsipprinsip khusus yang membentuk respon terhadap situasi khusus. Pada tahap kedua kita harus membuat sebuah upaya sistematis untuk memperoleh prinsip-prinsip dari aturan-aturan khususnya dan kemudian mengeneralisirnya sebagai hukum moral dan etik. ${ }^{57}$

Dikarenakan keadaan saat ini dalam hal-hal dan aspek penting tertentu dalam konteks sosial tidaklah sama persis dengan saat nabi Muhammad, maka gerakan kedua metodologi interpretasi Rahman adalah gerakan dari pandangan umum di atas menuju pandangan khusus yaitu yang harus diformulasikan dan realisasikan saat ini. Pada gerak ini Rahman menguraikan : That is, the general has to be embodied in the present concrete sociohistorical context. This once again requires the careful study of the present situation and the analysis of its various component elements so we can assess the current situation and change the present to whatever necessary, and so we can determine priorities afresh in order to implement the qur'anic values. ${ }^{58}$

Dengan kata-kata "mengubah keadaan saat ini menjadi kebutuhan apapun yang esensial" dan "menentukan kembali prioritas" Rahman ingin memperlihatkan sikap selektifitasnya akan realitas modern khususnya dampak budaya Barat dan secara langsung pula mengindikasikan sikap normatifitasnya kepada teks al-Qur'an sebagaimana yang dinyatakannya:

We must study the current situation thoroughly through the instrumentality of the social scientist. Ofcourse not all that there is in the current situation that need to be exercised and man's moral personality has to be reconstituted as it has been damaged by certain modern social and political developments. Then we apply those general principles of the Qur'an to the current situation espousing that which is worthy of esposing and rejecting that which must be rejected. $^{59}$

\section{Dari Kontekstual Historis Ke Dekontekstual Eksistensial}

Akibat persentuhan dunia Islam dengan budaya dan pengetahuan Barat kajian metodologi tafsir semakinmeluas Dengan terbukanya kajian terhadap teks agama problem hermeneutis belumlah tuntas sama sekali. Persoalan berikutnya yang bersifat metodologis pun mencuat; apakah pemahaman terhadap teks agama tersebut cenderung menjustifikasi normatifitas transendensi teks

\footnotetext{
${ }^{57}$ Rahman, Interpreting ..., hal. 49.

${ }^{58}$ Rahman, Islam and Modernity, hal. 7.

${ }^{59}$ Rahman, "Interpreting ...", hal. 49.
} 
agama tersebut atau malah memberikan keleluasaan bagi historisitas sang pembaca ?. Dengan kata lain, untuk mempertahankan normatifitas teks agama tersebut, apakah sang pengarang (zat transenden yang menggariskan makna awal teks) mesti mengintervensi dan mengkooptasi makna pemahaman sang pembaca, sehingga pembaca hanya bersifat mengulang kembali makna yang diinginkan sang pengarang tersebut?.

Apa yang menjadi pegangan hermeneutika tiga tokoh di atas masuk dalam kategori hermeneutika dengan kecenderungan metodologi "sisi pengarang" yang dipengaruhi oleh historisisme ${ }^{60}$ dan psikologisme pengarang hasil olahan Schleiermarcher dan Dilthey, yang kemudian diteruskan oleh Emilio Betti. Dalam tipologi hermeneutika ini pemahaman atau interpretasi diarahkan kepada apa yang dimasudkan sebenarnya oleh pengarang. "To understand the author is better than he understood himself" merupakan ikon metodologi interpretasi model hermeneutika objektif ini. Untuk memahami maskud yang diingini pengarang, pembaca, dengan begitu, harus menjelajahi psikologisme pengarang serta historisitasnya. Hanya dengan cara demikianlah pembaca dapat menelusuri metode-metode yang mengantarkannya memahami apa yang sebenarnya diingini pengarang tersebut.

Melalui pendekatan kontekstual dengan kecenderungan historisisme dan psikologisme ini tidak diragukan lagi teks, melalui keterikatannya dengan pengarang, lah yang memperngaruhi interpretasi pembaca. Dalam skema Thiselton, model ini merupakan model dominasi pengarang dalam transformasi makna teks. ${ }^{62}$ Pembaca hanya bersifat inferior di bawah superioritas pengarang. Ini lebih dikarenakan teks, dengan dominasi absolutilitas pengarang, dijadikan sebagai "subjek kajian", sementara pembaca hanya sebagai "objek kajian".63 Sedemikian rupa, sehingga interpretasi, melalui model ini, hanya bersifat reproduktif - meminjam istilah Gadamer ${ }^{64}--$; sekedar mengulang kembali makna yang diingini pengarang. Tidak ada something new dalam interpretasi wacana model ini.

60 Tamara Sonn menyebutkan bahwa historisisme adalah gerakan intelektual yang menggagas kebangkitan masyarakat melalui pengaplikasian nilai-nilai standar klasik. Historisisme di Barat bermula pada akhir abad IXX yang biasanya digunakan untuk mengacu kepada pengakuan atas dampak-dampak situasi khusus sosio-ekonomi dan politik pada formulasi budaya tertentu, termasuk formulasi yang menacaukp warisan keagamaan. Lihat Tamara Sonn, "Fazlur Rahman's Islamic Methodology" dalam Muslim World, 81/3-4, 1991, hal. 227

${ }^{61}$ Hirsch, Validity in Interpretation New Haven: Yale Univ. Press, 1967, hal. 207

${ }^{62}$ Lihat Anhtony C. Thiselton, New Horizon in Hermeneutics, Michigan: Zondervan Pub. House, 1992, hal. 31-36

${ }^{63}$ Lihat M. Amin Abdullah, “al-Ta'wil al-'Ilmi: Ke Arah Perubahan Paradigma Penafsiran Kitab Suci” dalam al-Jami'ah Vol. 39 No. 2 2001, hal. 361-362, atau Lihat Juga M. Amin Abdullah, Islamic Studies di Perguruan Tinggi: Pendekatan Integratif Interkonektif, Yogyakarta: Pustaka Pelajar, 2006, hal. 184-185.

64 Hans-Georg Gadamer, Philosophical Hermeneutics, Barkeley: Univ. of California Press, 1976hal. 105 
Paradigma kontekstualisasi dalam analisis wacana di atas jelas mengarah kepada survivalitas dan kebermaknaan teks, namun di sisi lain kurang memberikan ruang bagi kebermaknaan indvidu dan pemberdayaannya. Hal terakhir inilah yang menjadi kritik eksistensialisme terhadap teori wacana. Tipologi kontekstualisasi wacana, menurut Heidegger, telah mengeliminir eksistensi sang pembaca dan penafsir. Ia berpandangan bahwa apa yang pertama kali dipahami dalam sebuah wacana bukanlah orang lain, melainkan sebuah "proyeksi", yakni outline cara baru keberadaan di dunia. Hanya dengan tulisan yang membebaskan teks, tidak hanya dari pengarang dan audiens aslinya, namun juga dari sempitnya situasi dialogis, yang mengilhami masa depan wacana sebagai proyeksi sebuah dunia. ${ }^{65}$ Dengan kata lain "proyeksi" keberadaan diri seseorang serta keberlangsungan wacana secara universal hanya dapat dilakukan dengan dekontekstualisasi wacana.

Heidegger dapat dipandang sebagai filosuf yang pertama kali membuka pintu bagi pendekatan dekontekstualisasi wacana. Pemikiran Heidegger ini mendapatkan sambutan hangat khususnya bagi human sciences yang sedang mencari identitas metodologi distinktif dari natural sciences. ${ }^{66}$ Apalagi kemudian diinjeksikan oleh Gadamer dengan pendekatan filosofisnya. Shifting of paradigm dari pemahaman bernuansa epistemologik dalam mazhab pertama di atas ke arah pemahaman rada ontologik dari Heidegger semakin diperkuat oleh murid Heidegger ini dengan meniupkan nafas fenomenologi ke dalam ruh paradigma ini. Gadamer berpandangan bahwa orientasi psikologisme pengarang menyalahi tradisi dan tidak memenuhi "historical consciousness", karena hanya mengedepankan historisitas pengarang. Pembaca atau penafsir menjadi a historis. Padahal, lanjut Gadamer, pemahaman seharusnya tidak dipahami sebagai proses subjektif manusia. ${ }^{67}$ Dengan pemahaman menyejarahnya bahwa "to be historical that every human knowledge never be complete" Gadamer menegaskan bahwa pemahaman atau penafsiran harus bersifat kreatif: melahirkan penafsiran yang baru. Penafsiran harus bersifat produktif - bukan reproduktif sebagaimana orientasi psikologisasi pengarang - karena "the interpretation of a text, is not passive openness but dialectical interaction with the text; it is not bald reenactment but a new creation, a new event in understanding. ${ }^{68}$

Menguatnya eksistensialisme dan fenomenologi dalam kajian keilmuan memberikan dampak yang sangat signifikan terhadap teks, khususnya otonomi teks. Sisi teks dan penafsir yang termarjinalkan sebelumnya mendapatkan pemberdayaan dalam porsi yang mengagumkan. Terhadap studi

${ }^{65}$ Martin Heidegger, Being and Times, Oxford: Blackwell, 1962., hal. 962

66 Kecenderungan metodologis aliran kontekstulisasi wacana dengan mengedpankan norma-norma yang harus diikuti oleh pembaca untuk sampai kepada makna yang diingini pengarang merupakan kecenderungan yang diadopsi dari natural sciences untuk diterapkan ke dalam human sciences, di mana objektifikasi, verifikasi dan keterukuran merupakan elemenelemen kuncinya, lihat Hans-Georg Gadamer, Truth and Method, New York: The Seabury Press, 1975, hal. 5-10

${ }^{67}$ Gadamer, Truth and Method, hal. 275.

${ }^{68}$ Gadamer, Philosophical Hermeneutics, hal. 105. 
Islam atau tafsir maka fenomena ini menandai adanya peralihan dari studi teks agama (Islam) sebagai subjek studi menjadi studi teks agama sebagai objek studi.

\section{Penutup}

Elaborasi umum wawasan hermeneutika dan pemeriannya serta tradisi hermeneutika dan tafsir dalam dunia Islam menunjukkan bahwa distinksi antara hermeneutika dan tafisr tidak hanya semata defenisi dan cakupan objek kajian. Secara teoritik cakupan kajian, hermeneutika memfokuskan diri pada teori atau metodologi penafsiran. Sementara itu tafsir lebih pada praksis penafsiran, meskipun sebenarnya dalam kenyataanya tafsir al-Qur'an juga mengandung metodologinya (yang tidak terteoritisasi) seperti asbab al nuzul serta pemakaian kaidah ushul al-fiqh. Perbedaan fundamental antara ke dua tema tersebut adalah pijakan yang mendasari hermeneutika dan tafsir.

Tafsir bersandarkan pada tradisi dalam kesejarahan efektif Islam baik yang mencakup tradisi pengalaman keberagamaan, maupun tradisi keilmuan Islam itu sendiri. Setidaknya ada tiga pendekatan yang cukup kental dalam tafsir al-Qur'an. Pertama, Pendekatan gramatikal-tekstual berdasarkan argumentasi bahwa alQur'an telah sempurna dengan dirinya sendiri yang kandungannya dapat dipahami dengan kemukjizatan bahasanya. Ke dua, Pendekatan profetik dengan mengedapankan pribadi Muhammad sebagai peran pengganti pengarang (tafsir bi al-Ma'tsur). Ketiga pendekatan mistikal yang lebih mementingkan substansi makna dalam proposisi bahasa. ${ }^{69}$ Ke tiga pendekatan ini memperlihatkan betapa tingginya pengalaman keberagamaan yang terikat dengan "keimanan" seorang muslim dalam menafsirkan al-Qur'an. Hal terakhir ini dalam keilmuan Islam dikenal sebagai tafsir esoterik atau, meminjam istilah Henry Corbin, ${ }^{70}$ ta'wil (spiritual interpretation) di mana kebenaran makna al-Qur'an tidak berada dalam huruf dan kalimat, melainkan dalam pengalaman batin. Sedangkan hermeneutika menemukan peijakannya pada pemikiran spekulatif filsafat yang lebih mengedepankan nalar atau rasio. Bila tafsir lebih bernuansa pengalaman batin (keimanan dan keberagamaan), maka hermeneutika didominasi oleh nalar spekulatif atau filsafat.

\section{Daftar Pustaka}

Earle H. Waugh, The Shaping of an American Islamic Discourse, Atalanta: Schloar Press, 1998

-------, Wacana Islam Barat, terj. Musnur Hery, Yogyakarta: TIP., 2001

${ }^{69}$ Komarudin Hidayat, Memahami Bahasa Agama... , hal. 149.

${ }^{70}$ Henry Corbin, History of Islamic Philosophy (London: Kegan Paul, 1993) hal. 12. Lihat pula Charles J. Adams, "The Hermeneutics of Henry Corbin" dalam Richard Martin ed. Approaches to Islamic Religious Studies (Tucson: Univ. of Arizona Press, 1985) hal. 129-50 Juga lihat Yusuf Rahman "Spiritual Hermeneutics (Ta'wil): A Study of Henry Corbin's Pehenomenological Appraoch" dalam al-Jami'ah No. 62/XII/1998, hal. 1-13. 
Daniel Brown Rethinking Tradition in Modern Islamic Thought, Cambridge: Cambridge Univ. Press, 1996

Mircea Eliade (ed. In chief), The Encyclopedia of Religion, vol. 13, New York: MacMillan Pub. Comp., 1987

Fazlur Rahman, "Divine Revelation and the Prophet" dalam Hamdard Islamicus, 3:2 June 1964

--------, Interpreting the Qur'an dalam Inquiry, Mei, 1986

-------, "Approaches to Islam in Religious Studies: Review Essay", dalam Richard C. Martin, Approaches to Islam in Religious Studies (Tucson: Univ. of Arizona Press, 1985)

-------, Islam \& Modernity, Chicago: Chicago Univ. Press, 1982

Paul Ricoeur, "Philophy and Relligious Language" dalam Journal of Religion, No. 54, 1974

1978

-------, Main Trends in Philosophy, New York: Holmes and Heimer Pub.,

-------, From Text to Action: Essays in Hermeneutics II , Evanston: Northwestern Univ. Press, 1991

-------, Interpretation Theory, Discourse and the Surplus of Meaning

Texas: Texas Christian Univ. Press, t.t ,

, Filsafat Wacana: Membelah Makna Dalam Anatomi Bahasa, terj.

Musnur Hery, Yogyakarta: Irchisod, 2002

1974

--------, The Conflict of Interpretation Evanston: Northestern Univ. Press,

--------, Hermeneutics and the Human Sciences, Cambridge: Cambridge University Press, 1981

M. Arkoun, al-Islam: al-Akhlaq wa al-Siyasah, terj. Beirut: Markaz alInma' al-Qaumi, 1990

M. Amin Abdullah, Rekosntruksi Metodologi Ilmu-ilmu keIslaman, Yogyakarta: SUKA Press, 2003

-------, 'al-Ta'wil al-'Ilmi: Ke Arah Perubahan Paradigma Penafsiran Kitab Suci” dalam al-Jami’ah Vol. 39 No. 2 , 2001

-------, Islamic Studies di Perguruan Tinggi: Pendekatan Integratif Interkonektif, Yogyakarta: Pustaka Pelajar, 2006

Tamara Sonn, "Fazlur Rahman's Islamic Methodology" dalam Muslim World, 81/3-4, 1991

Hirsch, Validity in Interpretation New Haven: Yale Univ. Press, 1967

Heru Prakosa, Fazlur Rahman and His Qur'anic Hermeneutics, Oxford, 2001

Azizah al-Hibri, "A Study of Islamic Herstory": Or How Did We Ever Get Into This Mess?, dalam Women's Studies International Forum.5/2, 1982

Aminah Wadud Muhsin, The Qur'an and Woman Kuala Lumpur: Penerbit Fajar Bakti, 1992

Farid Essack, Qur'an, Liberation and Pluralisme: An Islamic Perspective of Interreligious Solidarity gainst Oppression, Oxford: Oneworld, 1997

Josep Bleicher, Contemporary Hermeneutics: Hermeneutics as Methods, Philosophy and Critique, London: Rouledge and Kegan Paul, 1980 
Anhtony C. Thiselton, New Horizon in Hermeneutics, Michigan: Zondervan Pub. House, 1992

Hans-Georg Gadamer, Philosophical Hermeneutics, Barkeley: Univ. of California Press, 1976

--------, Truth and Method, New York: The Seabury Press, 1975

Martin Heidegger, Being and Times, Oxford: Blackwell, 1962

Richard E. Palmer, Hermeneutics : Interpretation Theory in Schleirmarcher, Dilthey, Heidegger and Gadamer, Evanstone: Northwestern University Press, 1969

-------, Hermeneutika: Teori Baru Mengenai Interpretasi, terj. Musnur Hery dan Damanhuri , Yogyakarta: Pustaka Pelajar, 2003 Press, 1971

Benveniste, Problems in General Linguistcs Florida: Univ. of Miami

Roland Barthes, The Pleasure of the Text, New York: Hill and Wang, 1975 and Wang, 1977

-, The death of the author" dalam Image-Music-Text, London: Hill

Derrida, Deconstruction and Criticism , London: Routdeledge and Kegan Paul, 1979

Karl Marx dan Frederick Angels, On Religion, Moscow: Publicity House, 1955

-------, Writing of Young Marx on Philosophy and Society, New York: Doubleday, Anchor Books, 1967

-------, "Contribution to the Critique of Hegel's Philosophy of Right' dalam Early Writings, New York: McGraw-Hill, 1964

Richard Kearney, Religion and Ideology : Paul Ricoeur's Hermeneutic Conflict dalam The Iris Theological Quarterly,

Flores, Wrestling With the Text: Paul Ricoeur's Hermeneutics and the Historical Method in Biblical Exegesis, Diwa 27 November 2002

Haryatmoko, "Transparansi Sebagai Proses", Basis 05-06 (2001)

Friedrich Nietzsche, Beyond Good and Evil New York: Random House Vintage Books, 1966

Sigmund Freud, The Future of an Illusions, New York: W.W. Norton \& Compant, 1961

John B. Thompson, Studies in the Theory of Ideology, California: Univ. Of California Pess, 1984

Iqbal, . The Reconstruction of Religious Thought in Islam , Lahore: Iqbal Academy Pakistan, 1989. 1996

Komarudin Hidayat, Memahami Bahasa Agama, Jakarta: Paramadina, 